\title{
Locating North Carolina Cartographic Information
}

\author{
Ralph Lee Scott
}

Map information about North Carolina can be a useful tool for historical research, legal research, hiking, camping, teaching, and display. Maps are a colorful graphic representation of familiar and unfamiliar geographic features ranging from geologic faults to your own backyard. Maps are available in a wide variety of types. Topographic, geologic, bathymetric, geophysical, historical, planimetric, hydrologic, nautical, land use, land cover, transportation, highway, river, recreational, soil survey, mineral, climatic, and satellite image maps can all be found for portions of North Carolina. How does one go about acquiring North Carolina maps of interest or deciding which map best meets a need? After reading this article you should have a general idea of where to go next for help.

A good source of North Carolina mapping is the North Carolina affiliate of the National Cartographic Information Center (NCIC), the North Carolina Geological Survey, located on the fifth floor of the Archdale Building in Raleigh. Some of the products that NCGS can offer you are described below.

Currently some thirty federal agencies offer maps to the general public. These are available in conventional topographic maps, space/aerial photographs, and in digital form. The North Carolina Geological Survey assists citizens in locating cartographic materials that might be of use to them. The NCGS has the ability to locate needed maps through an in-house indexing system. If you want a topographic map or nautical chart of a North Carolina area, these are the folks to start with to find out what is available for your area.

In addition to current mapping, the NCGS also offers reproductions of older mapping printed "on photographic paper, at or near there (sic) original size." ${ }^{1}$ Genealogists frequently consult these early maps for information on current and defunct North Carolina towns. These older historical topographic maps date back to about 1879 ,

Ralph Lee Scott is head of the Documents Department/North Carolina Collection of Joyner Library at East Carolina University in Greenville, NC. when the United States Geological Survey was established. Some useful publications for locating older maps held by the federal government in their record centers are: Guide to Cartographic Records in the National Archives, ${ }^{2}$ and The Geography and Map Division: A Guide to Its Collections and Services, ${ }^{3}$ the latter of which covers maps in the Library of Congress. Older maps may be obtained also in federal documents depositories, state archives, local and county historical societies and county court houses.

The NCGS can also assist you in searching the files of the United States Board on Geographic Names which sets federal usage of place names in the world. The main name file is called the Geographic Names Information System, and it is indexed through the Geographic Names Alphabetical Finding List available through the NCGS.

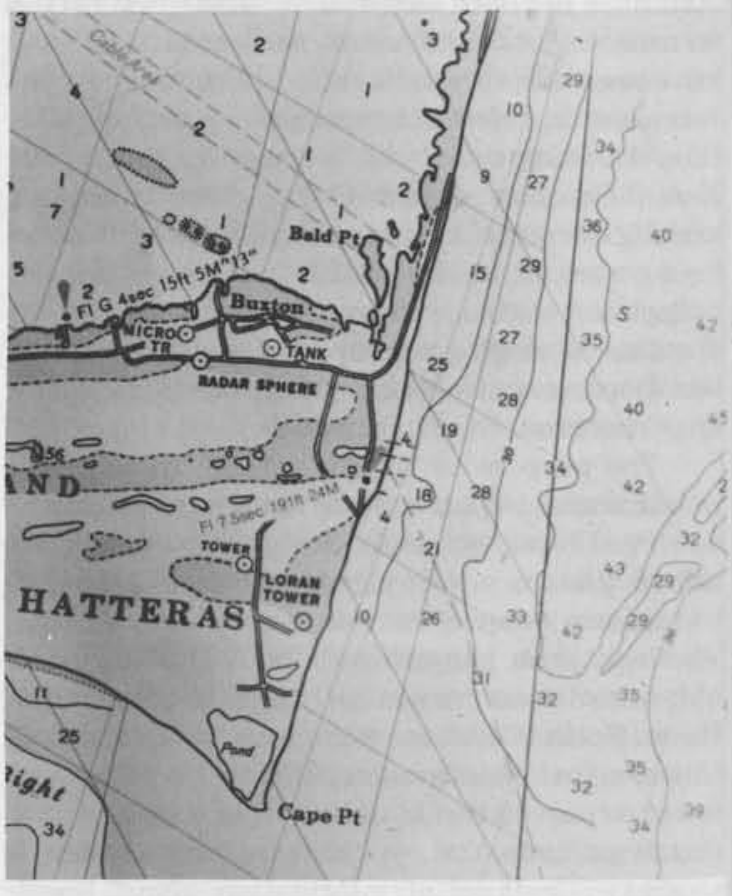

National Ocean Survey Hydrographic Chart-Cape HatterasWimble Shoals to Ocracoke Inlet, N.O.S. Chart 11555 (LoranC Overprinted), (Washington, NOAA, 1980), DMA Stock No. 11 AC011555. 
These lists which are available by state; contain the name (even if the name was discussed by the board and not used); a name class (school, lake, stream, locale, place, tank); a county code; coordinates; elevation and map code (for some names only). All sorts of interesting lists can be computer generated by NCGS. A list of place names for your county can be generated, for instance, from the Geographic Information System. Printed copies of state lists can be consulted at most federal document depositories. Currently the North Carolina Index is available only on computer printout, but some in-state libraries have this available for patrons to consult.

Another helpful agency to know about is the "Old Charts Section" of the National Oceanographic and Atmospheric Administration (NOAA) in Washington, D.C. They maintain files on the current and historical status of hydrographic mapping with emphasis on the United States coastal areas. For instance, if you want to find out when Bald Head Island was first charted, the "Old Charts Section" can consult their records by the current coastal chart number to determine when the area was first surveyed. All of the older charts have been sent to the National Archives where the charts are available to the public. Photocopies can be made by the National Archives of most older charts. They ask, however, that you first obtain the chart number from the "Old Charts Section" of NOAA before requesting a copy on Interlibrary Loan.

Aerial photographs are also available through the NC Geological Survey. For example, if you wanted an aerial photograph of Chapel Hill in the early twentieth century, any number of state, private, or federal agencies may have mapped this area. The NC Geological Survey would be able to assist you in getting the best source for a photograph. A wide variety of high-altitude (EROS satelite) photographs as well as low-altitude flyover photographs are available through this program.

Census tract maps are also a source of useful cartographic information. These maps are available back to the 1910 Census and show the location by city place names located within the census tract boundaries. It was not until the 1940 Census that North Carolina cities were first listed in published tract maps. These maps are often used by demographers and epidemiologists to pinpoint statistical trends. Starting with the 1990 Census, these maps will be in a computer readable file called TIGER (Topologically Integrated Geographic Encoding and Referencing) file. While there has been some recent criticism of the accuracy of some of the 1990 TIGER maps, the files are the

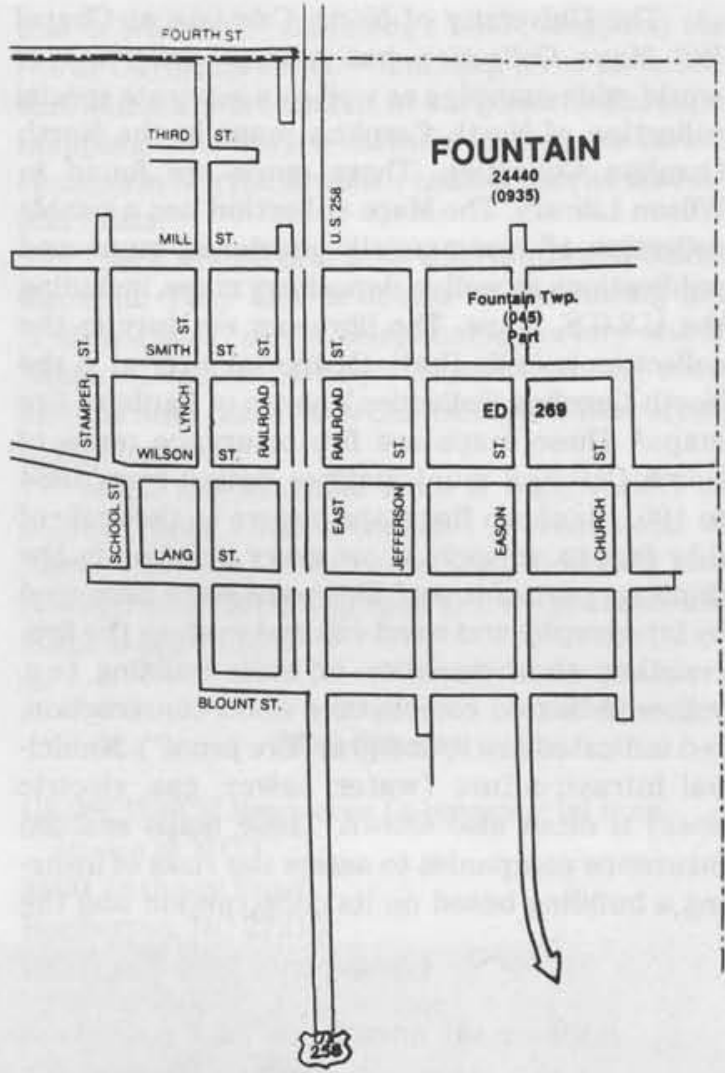

Census Tract Map, Fountain, N.C., (Washington, D.C., U.S. Dept. of Commerce, 1980).

first large scale attempt at computerized mapping of the United States. ${ }^{4}$

In addition to this federal aerial mapping, the Weyerhaeuser Company photographed most of eastern North Carolina, from the Virginia border to Bladen and Pender counties. These photographs are for sale by the Weyerhaeuser Company in prices varying from $\$ 12.00$ to $\$ 109.77$, depending on photograph size. Weyerhaeuser maps may be viewed at the Aerial Photo Sales Department Office in the Region Headquarters building of the Weyerhaeuser Company in New Bern, NC.

Map users may consult copies of maps in a wide variety of collections throughout North Carolina. Most federal documents depositories have some maps. Public libraries acquire local maps of interest to their patrons. Community colleges and technical institutes with surveying programs are also likely locations to find map collections. The largest map collections in the state are found at Duke University, the University of North Carolina at Chapel Hill and the State Archives in Raleigh. Most public and private universities and colleges in the state also have map collections that are open to the public. 
The University of North Carolina at Chapel Hill Maps Collection has a large collection of world-wide mapping as well as a separate special collection of North Carolina maps in the North Carolina Collection. These maps are found in Wilson Library. The Maps collection has a sizable collection of commercially produced maps and publications as well as depository maps, including the U.S.G.S. maps. The librarian on duty in the collection is Celia Pratt. Of special interest is the North Carolina Collection's series of Sanborn fire maps. ${ }^{5}$ These maps are fire insurance maps of North Carolina municipalities dating from 1884 to 1951. Sanborn fire maps, drawn to the scale of fifty feet to an inch, show every building in the "built up part of town." The maps were produced by lithography and hand-colored to show the fireresistant characteristics of each building (e.g. yellow indicated combustible wood construction, red indicated brick, and gray "fire proof"). Municipal infrastructure (water, sewer, gas, electric lines) is often also shown. These maps enabled insurance companies to assess the risks of insuring a building based on its construction and the construction of neighboring structures. The Great Depression and World War II greatly affected the ability of the company to produce these maps; they fell into disuse and the company never recovered financially. Today most of this information is stored on rate sheets by location in computers instead of in Sanborn fire map format. These maps however, still provide a great wealth of information on North Carolina towns and cities during the period they were produced in the state. Maps were updated periodically as needed, so you will find that date coverage will vary for given localities. Historians, genealogists, preservationists, and other researchers will find this series indispensable. Other maps of North Carolina historical interest will be found in this collection located in the Louis Round Wilson Library. The staff here is always eager to assist those researching North Carolina history. H. G. Jones is the North Carolina Collection curator.

The North Carolina State Archives in Raleigh, a division of the Department of Cultural Resources, collects original manuscripts and printed maps of North Carolina as well as facsimiles from

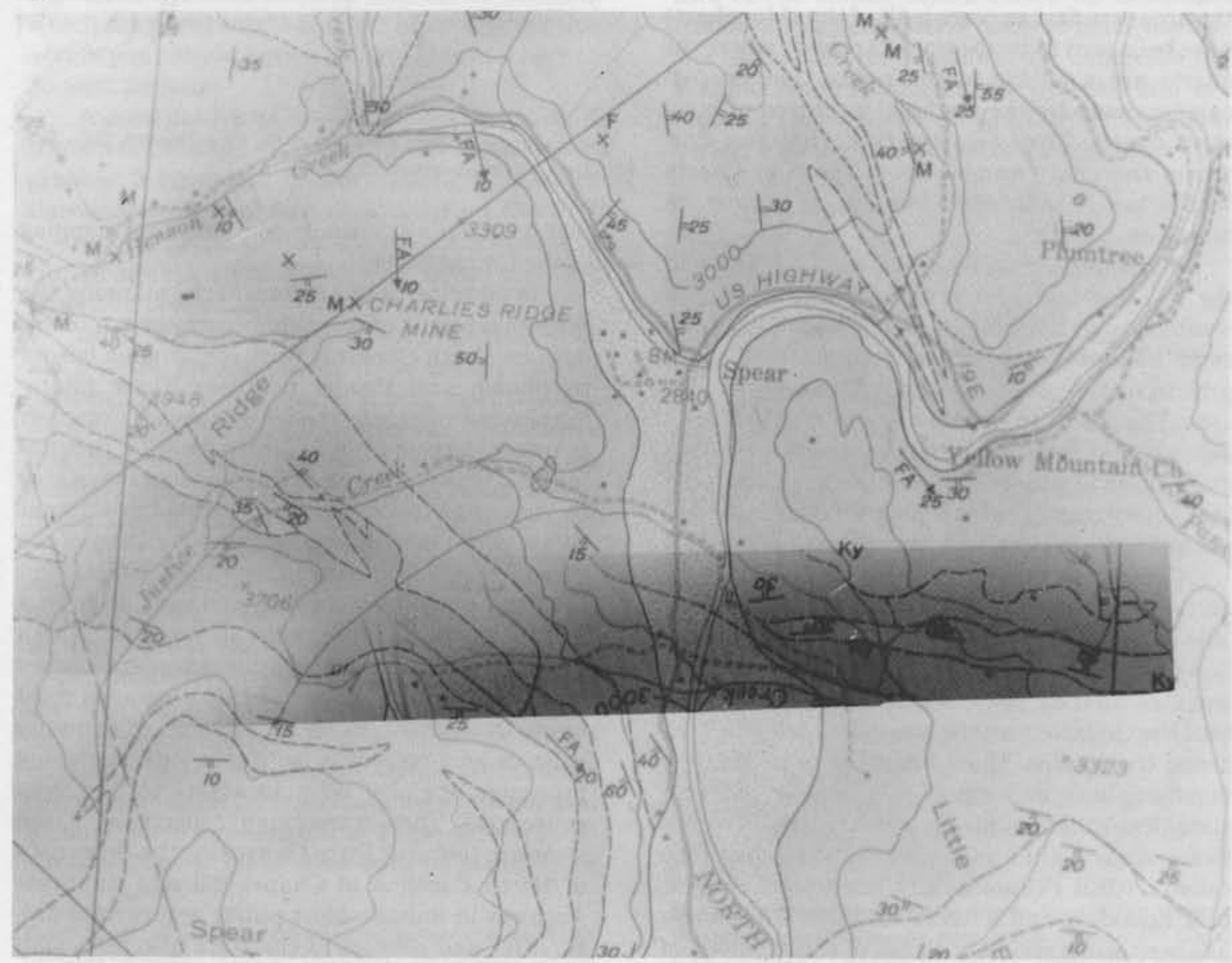

Topographic Map, Pinnacle, N.C., (Washington, D.C., USGS, 1964) AMS 4956 IV SW-Series V842 7.5 min. series. 
other collections. Land survey records from county court registers of deeds are kept here in microform (and in manuscript form if counties have sent the originals to the State Archives for preservation). Card files are maintained which chronologically, topically, and geographically index maps in the State Archives. Map collections of interest are the special surveys of eastern North Carolina swampland; records of the Department of Transportation, The North Carolina Wildlife Resources Commission, The North Carolina Ports Railway Commission; and various other state mapping agencies. The State Archives has in place a careful screening process to protect their valuable manuscript resources from theft and mutilation. Be sure to bring identification and allow extra time for registering to use their collection. Staff on duty in the search room can help you locate maps in their collection. ${ }^{6}$

Duke University has an extensive collection of USGS maps. This depository collection has been supplemented by university purchases of additional domestic and foreign maps both commercial and governmental. The Duke collection is open to the public and is located in the Documents Department of Perkins Library. The Duke University collection of non-U.S. mapping is the largest and most comprehensive in the state. Margaret Brill is the map librarian in the Duke Documents Department.

Most universities and colleges with geology programs also receive maps from the various State Geological Surveys. If you are interested in an area that has been mapped by a state survey then this type of map will prove to be of interest. Again the larger universities have the more extensive collections. For instance if you are interested in a Colorado map, then the Colorado Geological Survey might have done one. A call to the North Carolina Cartographic Information Center will tell you if out-of-state mapping exists for your area of interest.

Individuals working on North Carolina areas will not want to be without William Powell's North Carolina Gazetteer, ${ }^{7}$ which is the best source of local place name information and anecdote. If you are not satisfied with the sheet maps you have located so far you might want to consult David Clark's book Index to Maps of North Carolina in Books and Periodicals, ${ }^{8}$ alas now a decade and a half old and in need of updating. It does, however, cover books and periodicals published prior to 1974 and should be consulted. Often large atlases in the reference collection will have useful maps of North Carolina in them. Also of interest to researchers of the coastal areas of North Caro- lina is William P. Cumming's book, Mapping the North Carolina Coast. ${ }^{9}$ Cumming gives an excellent summary treatment of early North Carolina mapping. This work is useful in tracing the varied changes in North Carolina's coastal barrier islands and inlets.

There are several map distributors in North Carolina. They can be found by consulting the "Yellow Pages" of the telephone directory under "Maps-Dealers." A major North Carolina commercial map resource is GEOSCIENCE Resources, in Burlington.

Maps are available from a wide variety of sources, both commercial and governmental in North Carolina. They make ideal teaching and research aids. A bibliography and list of sources of maps is appended.

\section{Map Sources}

GEOSCIENCE Resources (a commercial map source in N.C.)

2990 Anthony Road

Burlington, NC 27215

(800) 742-2677 (order desk)

North Carolina Cartographic Information Center (NCIC)

P. O. Box 27687

Raleigh, NC 27611-7687

(919) 733-2423

\section{U.S. Library of Congress. Geography and} Map Division

Library of Congress

Washington, D.C. 20540

U. S. National Archives

Publications Sales Branch

Washington, D.C. 20408

U. S. National Cartographic Information Center 507 National Center

Reston, VA 22092

(703) $860-6045$

U. S. National Oceanographic and Atmospheric Administration

Old Charts Section

Rockville, MD 20852

(301) 436-5766

U. S. Government Printing Office

(Superintendent of Documents)

Washington, D.C. 20402

(Continued on page 149) 